\title{
Behavioral compression of polyolfin-aramid fiber and glass fiber on flexural strength of leca concrete
}

\begin{abstract}
Concrete is a very strong and versatile mouldable construction material. It consists of cement, sand and aggregate (e.g., gravel or crushed rock) mixed with water. Normal concrete has some defects like high cement consumption and heavy ingredients which cause to increase the concrete price. The aim of light weight concrete (LWC) is removing the common defects of normal concrete and remaining its advantages. The fiber concrete is one of the materials to enhance the strength and quality of LWC. It can use to strengthen the brittle concrete. In this study, the effect of Polyolefin-Aramid and glass fiber has been considered on flexural strength of LECA concrete. In this manner, the specimens were uused with $(15 * 15 * 15) \mathrm{cm}$ for compressive strength and prismatic strength with $(50 * 10 * 10) \mathrm{cm}$ for fflexural strength. In this test, the percent changes of Polyolefin-Aramid and glass fiber have been [considered. The amount of Polyolefin-Aramid is 5, 5.2 and 5.7 in each cubic meter and 3, 5.4 and 6 for glass have been assigned.
\end{abstract}

Keywords: leca concrete, light weight concrete (lwc), polyolefin-aramid, behavioral compression, glass fiber, flexural strength

\author{
Volume 4 Issue I - 2018
}

\author{
Nima Amani,' Ardalan Sabamehr, ${ }^{2}$ Hossein \\ Tayebi' \\ 'Department of Civil Engineering, Islamic Azad University, Iran \\ ${ }^{2}$ Department of Building, Civil and Environment Engineering, \\ Concordia University, Canada
}

Correspondence: Nima Amani, Assistant Professor, Department of Civil Engineering, Chalous Branch, Islamic Azad University, P.O. Box 46615-397, Chalous City, Mazandaran Province, Iran, Tel +989-I I 2-229-484,

Email nimaamani@iauc.ac.ir

Received: June 20, 2017 | Published: February 6, 2018

\section{Introduction}

LIGHTWEIGHT CONCRETE May consist of lightweight aggregates are used in ordinary concrete of coarse aggregate and sand, clay, foamed slag, clinker, crushed stone, aggregates of organic and inorganic. It used in different common shapes such as light weight aggregate concrete, ${ }^{1}$ concrete without fine ${ }^{2}$ or concrete with bubble ${ }^{3}$ . It is replaced by normal concrete in several applications because of its advantages like low specific weight and heat insulation. ${ }^{4}$ Fiber is a small piece of reinforcing material possessing certain characteristics properties which cause to improve the properties of concrete. Fiber have bonding in multi directions which avoid propagating a crack and increase the efficiency of concrete..$^{5-7}$

\section{Purpose of the study}

The main objective of this research is the effect of Polyolefin Aramid fiber and glass fiber in LECA (Light Expanded Clay Aggregate) concrete flexural strength.

\section{Materials and methods}

\section{Definition}

In this study, the effects of various percentage weights (in cubic meter) of Polyolefin Aramid fiber and Glass fiber have been investigated in LECA concrete. ${ }^{8}$ Then, three different percentages have been used with same concrete mix design. The tests duration is classified into 7-days and 28-days. The cubic and prismatic samples used for compressive and flexural strength respectively., ${ }^{9}$

\section{Ingredient}

Water: According to the Iranian Standard Concrete Code (ABA), clean water without any additive should be used in the concrete. Generally drinking water is suitable in concrete. ${ }^{11}$ In this test, the Sari city drinking water is used in concrete.

Cement: Here, Portland cement type II with $315 \mathrm{Kg} / \mathrm{m} 3$ specific weight has been selected. The modified Portland cement has an application in concrete which requires the hydration heating and mild sulfate attack. ${ }^{11,12}$

Micro silica: The multipurpose gel is advanced and multipurpose material to have a strong, sealed, impermeable, durable concrete with high flexural and tensile strength. The properties of this material is its high efficiency supplementary reaction in sake of absorbing the free lime and change water to Calcium Silicate which cause to reduce the Alkaline properties of concrete and avoid reacting silica-alkaline between aggregates ${ }^{13}$. The additive gel effect will be analyzed after using concrete based on ASTMC 1202-05 standard. The amount of Micro Silica gel is $5 \%$ of cement. ${ }^{14}$

Stone powder: Table 1 shows chemical analysis of stone powder.

Table I chemical properties of stone powder

\begin{tabular}{|c|c|c|c|c|c|c|c|c|c|c|c|}
\hline $\begin{array}{l}\text { Chemical } \\
\text { compounds }\end{array}$ & Chlorine & $\begin{array}{l}\text { Iron } \\
\text { oxide }\end{array}$ & $\begin{array}{l}\text { Aluminum } \\
\text { oxide }\end{array}$ & $\begin{array}{l}\text { Calcium } \\
\text { oxide }\end{array}$ & $\begin{array}{l}\text { Magnesium } \\
\text { oxide }\end{array}$ & $\begin{array}{l}\text { Sodium } \\
\text { oxide }\end{array}$ & $\begin{array}{l}\text { Potassium } \\
\text { oxide }\end{array}$ & $\begin{array}{l}\text { Phosphorus } \\
\text { oxide }\end{array}$ & $\begin{array}{l}\text { Sulfur } \\
\text { oxide }\end{array}$ & Other & $\begin{array}{l}\text { Drop } \\
\text { blush }\end{array}$ \\
\hline Constitutive \% & 0.02 & - & 0.5 & 55.4 & - & - & - & - & - & - & 43.13 \\
\hline
\end{tabular}

Natural aggregate: The sand is particles which have passed through a sieve No. 4. So, the size of sand is $0.5 \mathrm{~mm}$ in concrete with softness modulus of 3.04. The softness modulus evaluate the softness and coarseness of natural fine aggregate which should not be lower than 2.3 and greater than $3.1 .15,16$ 
LECA: The LECA has been used with 4-10 mm from Save LECA factory.

Polyolefin aramid fiber: The Polyolefin Aramid fiber is used as a reinforced material for concrete or mortar or asphalt in order to reduce the condensation and control the fraction and increase the long term durability. This kind of fiber has ineffective chemical material and it remains in alkaline environment without any problem. ${ }^{5,16}$ The physical properties of Polyolefin-aramid fiber include: Preliminary material: Polyolefin/aramid; Physical shape: reticular string and single string fiber; Specific weight: 0.91-1.44 gr/cm3; Tensile strength: $2800 \mathrm{Mpa}$ Length: $19 \mathrm{~mm}$ and $50 \mathrm{~mm}$; Color: yellow, black, yellowish brown and gray; Resistant on acidic and alkaline environment; Melting point: $100-427^{\circ} \mathrm{C}$. In this research, $19 \mathrm{~mm}$ polyolefin Aramid fiber, 50 $\mathrm{mm}$ filamentous polyolefin fiber and 0.91-1.44 $\mathrm{gr} / \mathrm{cm} 3$ specific mass have been used. ${ }^{17}$

Glass fiber: It is a kind of hybrid fiber which is designed to reinforce

Table 2 The preliminary mix design of LECA concrete the concrete. It reduces the plastic condensation and hardening in concrete and increase the tensile, bending strength and longevity which resulting in reducing maintenance and repairing fees. The specific hybrid of this fiber includes of polyolefin Aramid fiber and glass. ${ }^{18,19}$ The physical properties of Physical properties ${ }^{17,20}$ include: Primary material: glass, polyolefin aramid; Physical shape: reticular string and single string fiber; Specific weight: $1.4-2.7 \mathrm{gr} / \mathrm{cm}^{3}$; Tensile strength: $1500 \mathrm{Mpa}$; Length: $19 \mathrm{~mm}$; Color: yellow, black, white.

\section{Preliminary mix design}

Three preliminary mix designs have been prepared in order to find an optimum mix design. ${ }^{21-23}$ The following table presents the preliminary tests for LECA concrete. ${ }^{23}$ The specific weight is not a calculated specific weight in this table, it is the specific weight per volume of 7 days concrete in water. The unit of material weight is in $\mathrm{kg} / \mathrm{m}^{3}$ units (Table $2 \& 3$ ).

\begin{tabular}{|c|c|c|c|c|c|c|c|c|}
\hline $\begin{array}{l}\text { Mixes } \\
\text { No. }\end{array}$ & $\begin{array}{l}\text { Cement } \\
(\mathrm{kg})\end{array}$ & $\begin{array}{l}\text { Sand } \\
\text { (kg) }\end{array}$ & Water(kg) & $\begin{array}{l}\text { Micro silica } \\
\text { jell (kg) }\end{array}$ & $\begin{array}{l}\text { Stone } \\
\text { powder }(\mathrm{kg})\end{array}$ & Leca(kg) & $\begin{array}{l}\text { Specific weight } \\
\text { of fresh concrete } \\
\left(\mathrm{kg} / \mathrm{m}^{3}\right)\end{array}$ & $\begin{array}{l}\text { Compressive } \\
\text { strength of cubic } \\
\text { sample } 7 \text { days (mpa) }\end{array}$ \\
\hline I & 400 & 715 & 180 & 20 & 120 & 320 & 1750 & 18-Jun \\
\hline 2 & 400 & 780 & 180 & 20 & 120 & 300 & 1800 & 19-Jun \\
\hline 3 & 400 & 850 & 180 & 20 & 120 & 270 & 1840 & 2I-Aug \\
\hline
\end{tabular}

Table 3 The final mix design of LECA concrete

\begin{tabular}{lllllll}
\hline Cement $(\mathbf{k g})$ & Sand $(\mathbf{k g})$ & Water $(\mathbf{k g})$ & Micro silica Jell $(\mathbf{k g})$ & Stone powder $(\mathbf{k g})$ & LECA $(\mathbf{k g})$ & Ratio $(w / c)$ \\
\hline 400 & 825 & 180 & 20 & 120 & 280 & $45 / 0$ \\
\hline
\end{tabular}

\section{The procedure of preparing the light concrete without fiber}

The preparation steps for making concrete include of weighing and mixing of ingredients. In order to reduce the negative effect of water absorption in mixture of concrete by light weight aggregate (LWA), pre-wetting of LWA has been done before mixing the materials. Therefore, the certain amount of water equal to $10 \%$ weight of the LECA LWA. This amount of water is considered in calculation of effective water cement ratio and reduce it from water in mixture. ${ }^{1,4}$ The Laboratory boutonniere is used to mix the material. The concrete is mixed for one minute before casting to make it uniform. To mix three materials, initially LWA and natural aggregate is added in mixture then cement is added into them, then it is blended in 30 minutes. Two third of water for concrete is added to the mixture while the mixture was rotating. The rest is blended with Micro Silica gel completely then add mixture. The total concrete mix design takes around 10 minutes from casting until its discharge. ${ }^{24} \mathrm{After}$ mixing, part of concrete are used for slump test. The result of slump test is illustrated in Table 4.

Table 4 LECA concrete Slump test result

\begin{tabular}{ll}
\hline Slump $(\mathbf{c m})$ & Design \\
\hline 6-May & LI \\
8-Mar & L2 \\
12 & L3 \\
10 & Lf \\
\hline
\end{tabular}

\section{How to make a LECA concrete}

In concrete, polyolefin aramid fiber or infusion glass fiber add in concrete after the indicated materials and Micro Silica gel. Although, the mixing time would be minimized to avoid the fiber damage due to stones abrasion after adding fiber. ${ }^{16}$ This concrete is poured in clean and lubricated $15 \times 15 \times 15 \mathrm{~cm}$ cubes in two layers and prismatic frames in three layers then they are compensated with density hammer by hand. ${ }^{9}$ After compacting, the samples keep in frame for 24 hours with wetted Tarpaulin. Then, they bring out precisely without any damage and impact to the frame and they keep between $20+2 \mathrm{c}$ until testing. ${ }^{9,25}$

\section{Compressive strength test for hardened concrete}

Generally, two types of compressive tests have been considered such as cube and cylinder test. The cube type is used in UK, German and most of the Europe counties. The cylinder type has been proposed by US, France and Australia. In this research, cubic specimens have been utilized for compressive strength. First, the specimens are placed in steel or cast-iron frame. The cubic frame shape, length of side and polishing the surface should be compatible with advised properties. ${ }^{9,20}$ After the processing, the specimens bring out from frame and they have kept in the pool with $20+2 \mathrm{c}$ temperature. ${ }^{9,20,25}$ Before testing, the specimens come out from the pool and their surface has become dry. Then testing cubic specimens have been placed between two surfaces of machine in the direction which sample is in contact with cubic frame. Now, the vertical forced have been applied to the samples with constant velocity until the cube will break due to compressive force. The force which is written in digital screen of machine will be 
recorded and the compressive strength will be achieved by division of this force to the cube surface. ${ }^{9,20}$

\section{Flexural strength test26}

To calculate the flexural strength, the prismatic samples have been used with 10x10x5 cm according to ASTM C293 standard. ${ }^{10}$ For the processing, after placing the prismatic samples under the flexural strength machine, the load will be increased by hydraulic jack continuously until sample cracked and broken. Then last load have been read from machine screen and have been recorded. ${ }^{5}$

The corresponding device is the electrical flexural jack machine with 60 ton capacity. This machine is used to find the flexural strength of concrete in the simple concrete beam with center point load. ${ }^{16}$ The modulus of rupture has been computed as follows:

$$
R=3 P L / b d 2
$$

Which is: P: maximum applied load from machine Lbf $(\mathrm{N})$; L: length of span in $(\mathrm{mm}) \mathrm{b}$ : the width average of sample in $(\mathrm{mm})$; $\mathrm{d}$ : the depth average of sample in (mm); R: modulus of rupture psi (Mpa).

\section{Results and findings}

\section{The compressive strength}

It has been performed base on BS-1881 standard in cubic samples with $150 \mathrm{~mm}$. in this method, axial load test has applied in samples with certain value and it keeps until their failure. The compressive strength have been achieved by division of maximum applied load to the cross section. This test is done on hardened concrete in 7 and 28 days. Thus, 4 samples from each mix design have utilized for compressive test which the result show in Table 5. As it was expected, the compressive strength is enhanced with increasing the light weight concrete density. L3 sample has the high compressive strength with high specific mass concrete. The LECA concrete compressive strength results are mentioned in Table 5 for 7 and 28 days specimens.

Table 5 The sample with LECA compressive strength results

\begin{tabular}{llll}
\hline Sample & Test No. & Average resistance $\mathbf{7}$ days $\mathbf{( M P a})$ & Average resistance 28 days $(\mathbf{M P a})$ \\
\hline \multirow{2}{*}{ LI } & I & 18.4 & 21.7 \\
& 2 & 18.8 & 21.9 \\
& Average & 18.6 & 21.8 \\
L2 & I & 19.9 & 23.7 \\
& 2 & 19.3 & 23.5 \\
& Average & 19.6 & 23.6 \\
L3 & I & 21.5 & 25.6 \\
& 2 & 21.1 & 26.2 \\
& Average & 21.8 & 25.9 \\
& I & 20.7 & 25.1 \\
L4 & 2 & 20.3 & 24.7 \\
& Average & 20.5 & 24.9 \\
\hline
\end{tabular}

\section{Flexural strength}

It is used base on ASTM C293 standard in prismatic samples with 100x10x10 mm for 7 and 28 days specimens. In this method, prismatic samples have placed horizontally under jack between two support and the load has applied in one point in the middle of span until its failure. The flexural strength have been used for 7-days and 28-days hardened concrete. Three number of each fiber and 5 test for each one are considered.

\section{Poly Polyolefin-Aramid fiber test results}

For the test with polyolefin string fiber and polyolefin aramid fiber, two specimens for each of three fibers and 2 control samples for their
7 days and 3 samples for each of three fibers and three control samples for theirs 28 days have been tested for flexural strength. The results of 7 days flexural strength are indicated in Table 6 and the results if 28 days flexural strength are shown in Table 7. Furthermore, the flexural strength result of LECA concrete and polyolefin aramid fiber is illustrated in Figure 1 until 3 for 7 days and 28 days specimens. According to the results, it displays that polyolefin fiber results in enhancing the flexural strength. As it is shown in Figure 1, there is $45 \%$ enhancement for $6 \mathrm{~kg} / \mathrm{m}^{3}$ polyolefin string fiber and $1.5 \mathrm{~kg} / \mathrm{m}^{3}$ polyolefin Aramid fiber (Figures 1-3). According to the results, it displays that polyolefin fiber results in enhancing the flexural strength. As it is shown in Figure 6, there is $45 \%$ enhancement for $6 \mathrm{~kg} / \mathrm{m} 3$ polyolefin string fiber and $1.5 \mathrm{~kg} / \mathrm{m} 3$ polyolefin Aramid fiber.

Table 6 Flexural strength test result for 7-days LECA concrete and polyolefin aramid

\begin{tabular}{|c|c|c|c|c|c|c|c|c|}
\hline $\begin{array}{l}\text { Average } \\
\text { (MPa) }\end{array}$ & $\begin{array}{l}\text { Modulus } \\
\text { of rupture } \\
\text { (MPa) }\end{array}$ & $\begin{array}{l}\text { Sample } \\
\text { high } \\
(\mathrm{mm})\end{array}$ & $\begin{array}{l}\text { Sample } \\
\text { length } \\
(\mathrm{mm})\end{array}$ & $\begin{array}{l}\text { Sample } \\
\text { width } \\
(\mathrm{mm})\end{array}$ & Sample & $\begin{array}{l}19 \mathrm{~mm} \text { polyolefin } \\
\text { aramid fiber } \\
\left(\mathrm{kg} / \mathrm{m}^{3}\right)\end{array}$ & $\begin{array}{l}\text { Filamentous } \\
\text { polyolefin fiber with } \\
50 \mathrm{~mm}\left(\mathrm{~kg} / \mathrm{m}^{3}\right)\end{array}$ & Design \\
\hline \multirow{2}{*}{ 3-Sep } & Mar-8 & 100 & 300 & 100 & 1 & \multirow{2}{*}{$0 / 5$} & \multirow{2}{*}{2} & \multirow{2}{*}{ PAI } \\
\hline & $3 / 94$ & 100 & 300 & 100 & 2 & & & \\
\hline \multirow{2}{*}{ 4-Jan } & Feb-4 & 100 & 300 & 100 & I & \multirow{2}{*}{ I } & \multirow{2}{*}{4} & \multirow{2}{*}{$\mathrm{PA} 2$} \\
\hline & 4 & 100 & 300 & 100 & 2 & & & \\
\hline
\end{tabular}


Table Continues...

\begin{tabular}{|c|c|c|c|c|c|c|c|c|}
\hline $\begin{array}{l}\text { Average } \\
(\mathrm{MPa})\end{array}$ & $\begin{array}{l}\text { Modulus } \\
\text { of rupture } \\
(\mathrm{MPa})\end{array}$ & $\begin{array}{l}\text { Sample } \\
\text { high } \\
(\mathrm{mm})\end{array}$ & $\begin{array}{l}\text { Sample } \\
\text { length } \\
(\mathrm{mm})\end{array}$ & $\begin{array}{l}\text { Sample } \\
\text { width } \\
(\mathrm{mm})\end{array}$ & Sample & $\begin{array}{l}19 \mathrm{~mm} \text { polyolefin } \\
\text { aramid fiber } \\
\left(\mathrm{kg} / \mathrm{m}^{3}\right)\end{array}$ & $\begin{array}{l}\text { Filamentous } \\
\text { polyolefin fiber with } \\
50 \mathrm{~mm}\left(\mathrm{~kg} / \mathrm{m}^{3}\right)\end{array}$ & Design \\
\hline \multirow{2}{*}{$4 / 45$} & $4 / 53$ & 100 & 300 & 100 & I & \multirow{2}{*}{$1 / 5$} & \multirow{2}{*}{6} & \multirow{2}{*}{ PA3 } \\
\hline & $4 / 37$ & 100 & 300 & 100 & 2 & & & \\
\hline \multirow{2}{*}{ Feb-3 } & $3 / 26$ & 100 & 300 & 100 & I & \multirow{2}{*}{0} & \multirow{2}{*}{0} & \multirow{2}{*}{$\begin{array}{l}\text { Contro } \\
\text { sample }\end{array}$} \\
\hline & $3 / 14$ & 100 & 300 & 100 & 2 & & & \\
\hline
\end{tabular}

Table 7 Flexural strength test result for 28-days LECA concrete and Polyolefin aramid

\begin{tabular}{|c|c|c|c|c|c|c|c|c|}
\hline $\begin{array}{l}\text { Average } \\
(\mathrm{MPa})\end{array}$ & $\begin{array}{l}\text { Modulus } \\
\text { of rupture } \\
(\mathrm{MPa})\end{array}$ & $\begin{array}{l}\text { Sample } \\
\text { high } \\
(\mathrm{mm})\end{array}$ & $\begin{array}{l}\text { Sample } \\
\text { length } \\
(\mathrm{mm})\end{array}$ & $\begin{array}{l}\text { Sample } \\
\text { width } \\
(\mathrm{mm})\end{array}$ & Sample & $\begin{array}{l}19 \mathrm{~mm} \text { Polyolefin } \\
\text { Aramid fiber } \\
\left(\mathrm{kg} / \mathrm{m}^{3}\right)\end{array}$ & $\begin{array}{l}\text { Filamentous } \\
\text { Polyolefin fiber with } \\
50 \mathrm{~mm}\left(\mathrm{~kg} / \mathrm{m}^{3}\right)\end{array}$ & Design \\
\hline & $4 / 73$ & 100 & 300 & 100 & 1 & & & \\
\hline \multirow[t]{3}{*}{ 4/7I } & $4 / 64$ & 100 & 300 & 100 & 2 & $0 / 5$ & 2 & PAI \\
\hline & $4 / 76$ & 100 & 300 & 100 & 3 & & & \\
\hline & $5 / 19$ & 100 & 300 & 100 & I & & & \\
\hline \multirow[t]{3}{*}{$5 / 27$} & $5 / 33$ & 100 & 300 & 100 & 2 & I & 4 & PA2 \\
\hline & $5 / 29$ & 100 & 300 & 100 & 3 & & & \\
\hline & $5 / 78$ & 100 & 300 & 100 & I & & & \\
\hline \multirow[t]{3}{*}{$5 / 66$} & $5 / 52$ & 100 & 300 & 100 & 2 & $1 / 5$ & 6 & PA3 \\
\hline & $5 / 68$ & 100 & 300 & 100 & 3 & & & \\
\hline & Feb-4 & 100 & 300 & 100 & I & & & \\
\hline \multirow[t]{2}{*}{$3 / 9$} & $3 / 77$ & 100 & 300 & 100 & 2 & 0 & 0 & $\begin{array}{l}\text { Contro } \\
\text { Samplel }\end{array}$ \\
\hline & $3 / 91$ & 100 & 300 & 100 & 3 & & & \\
\hline
\end{tabular}

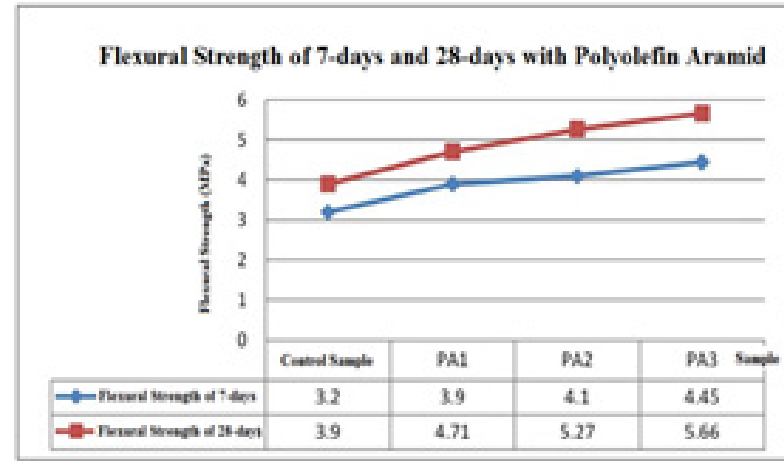

Figure I Comparison graph of the flexural strength in 7-days and 28-days of LECA concrete and polyolefin aramid.

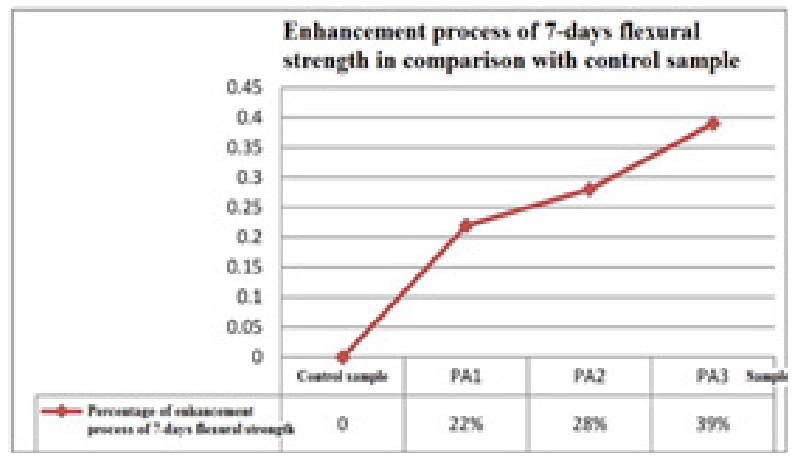

Figure 2 The enhancement process of 7-days flexural strength of LECA concrete and polyolefin aramid in comparison with control sample.

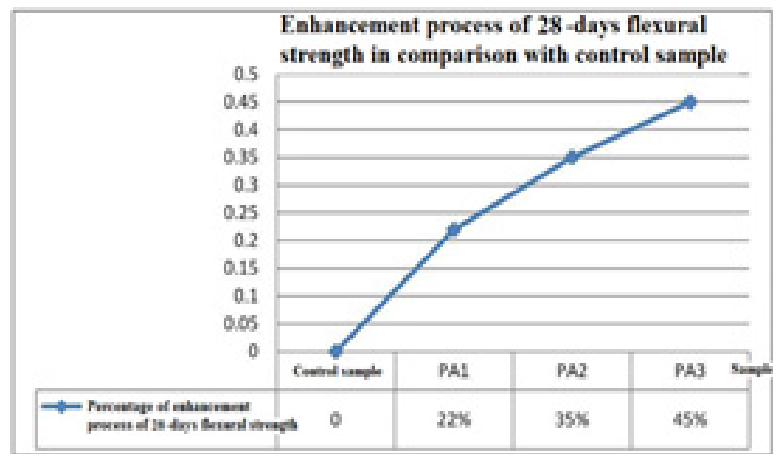

Figure 3 The enhancement process of 28 days flexural strength of LECA concrete and polyolefin Aramid in comparison with control sample.

\section{The results with glass fiber}

For this test, there are two specimens for each three fiber and two control samples for 7 days and three specimens for each three fibers and three control samples for 28 days which are considered for flexural strength test. The results of 7-days flexural strength are shown in Table 8 and theirs 28-days in Table 9. Meanwhile, the result of LECA concrete and glass fiber are illustrated in Figure 4 until 6 for 7-days and 28-days samples. According to the results, it shows that fiber glass cause to increase the flexural strength of the samples. According to the results, it shows that fiber glass cause to increase the flexural strength of the samples. As it indicated in Figure 2, there is $18 \%$ enhancement for $6 \mathrm{~kg} / \mathrm{m}^{3}$ glass fiber (Figures 4-6). 
Table 8 Flexural strength test result for 7 days LW concrete with glass fiber

\begin{tabular}{|c|c|c|c|c|c|c|c|}
\hline $\begin{array}{l}\text { Average } \\
(\mathrm{MPa})\end{array}$ & $\begin{array}{l}\text { Modulus of } \\
\text { rupture (MPa) }\end{array}$ & $\begin{array}{l}\text { Sample high } \\
(\mathrm{mm})\end{array}$ & $\begin{array}{l}\text { Sample } \\
\text { length }(\mathrm{mm})\end{array}$ & $\begin{array}{l}\text { Sample } \\
\text { width }(\mathrm{mm})\end{array}$ & Sample & $\begin{array}{l}19 \mathrm{~mm} \text { glass } \\
\text { fiber }\left(\mathrm{kg} / \mathrm{m}^{3}\right)\end{array}$ & Design \\
\hline & Mar-3 & 100 & 300 & 100 & I & & \\
\hline \multirow[t]{3}{*}{$36 / 3$} & & & & & & 3 & GI \\
\hline & $3 / 42$ & 100 & 300 & 100 & 2 & & \\
\hline & $3 / 53$ & 100 & 300 & 100 & I & & \\
\hline \multirow[t]{3}{*}{$59 / 3$} & & & & & & $4 / 5$ & G2 \\
\hline & $3 / 65$ & 100 & 300 & 100 & 2 & & \\
\hline & $3 / 74$ & 100 & 300 & 100 & I & & \\
\hline \multirow[t]{3}{*}{$71 / 3$} & & & & & & 6 & G3 \\
\hline & $3 / 68$ & 100 & 300 & 100 & 2 & & \\
\hline & $3 / 26$ & 100 & 300 & 100 & I & & \\
\hline \multirow[t]{2}{*}{$2 / 3$} & & & & & & 0 & $\begin{array}{l}\text { Control } \\
\text { sample }\end{array}$ \\
\hline & $3 / 14$ & 100 & 300 & 100 & 2 & & \\
\hline
\end{tabular}

Table 9 Flexural strength test result for 28 days LW concrete with glass fiber

\begin{tabular}{|c|c|c|c|c|c|c|c|}
\hline $\begin{array}{l}\text { Average } \\
(\mathrm{MPa})\end{array}$ & $\begin{array}{l}\text { Modulus of } \\
\text { rupture (MPa) }\end{array}$ & $\begin{array}{l}\text { Sample high } \\
(\mathrm{mm})\end{array}$ & $\begin{array}{l}\text { Sample } \\
\text { length }(\mathrm{mm})\end{array}$ & $\begin{array}{l}\text { Sample } \\
\text { width }(\mathrm{mm})\end{array}$ & Sample & $\begin{array}{l}19 \mathrm{~mm} \text { glass } \\
\text { fiber }\left(\mathrm{kg} / \mathrm{m}^{3}\right)\end{array}$ & Design \\
\hline & $1 / 4$ & 100 & 300 & 100 & I & & \\
\hline \multirow[t]{3}{*}{$4 / 17$} & $26 / 4$ & 100 & 300 & 100 & 2 & 3 & GI \\
\hline & $15 / 4$ & 100 & 300 & 100 & 3 & & \\
\hline & $3 I / 4$ & 100 & 300 & 100 & I & & \\
\hline \multirow[t]{3}{*}{$4 / 33$} & $47 / 4$ & 100 & 300 & 100 & 2 & $4 / 5$ & G2 \\
\hline & $21 / 4$ & 100 & 300 & 100 & 3 & & \\
\hline & $5 I / 4$ & 100 & 300 & 100 & I & & \\
\hline \multirow[t]{3}{*}{$4 / 61$} & $62 / 4$ & 100 & 300 & 100 & 2 & 6 & G3 \\
\hline & $7 / 4$ & 100 & 300 & 100 & 3 & & \\
\hline & 4-Feb & 100 & 300 & 100 & I & & \\
\hline \multirow[t]{2}{*}{$3 / 9$} & $77 / 3$ & 100 & 300 & 100 & 2 & 0 & $\begin{array}{l}\text { Control } \\
\text { sample }\end{array}$ \\
\hline & $91 / 3$ & 100 & 300 & 100 & 3 & & \\
\hline
\end{tabular}




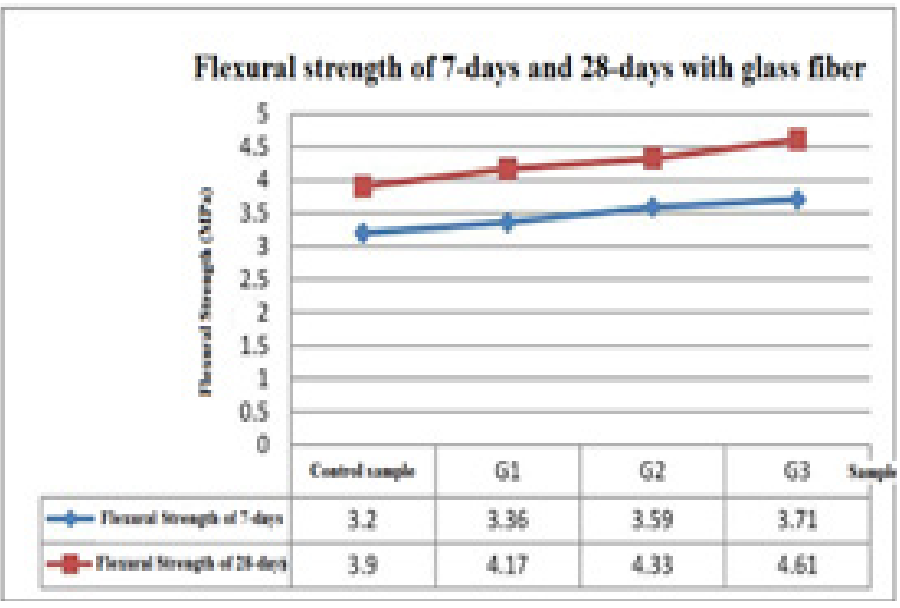

Figure 4 comparison graph of the flexural strength in 7 days and 28 days of LW concrete with glass fiber.

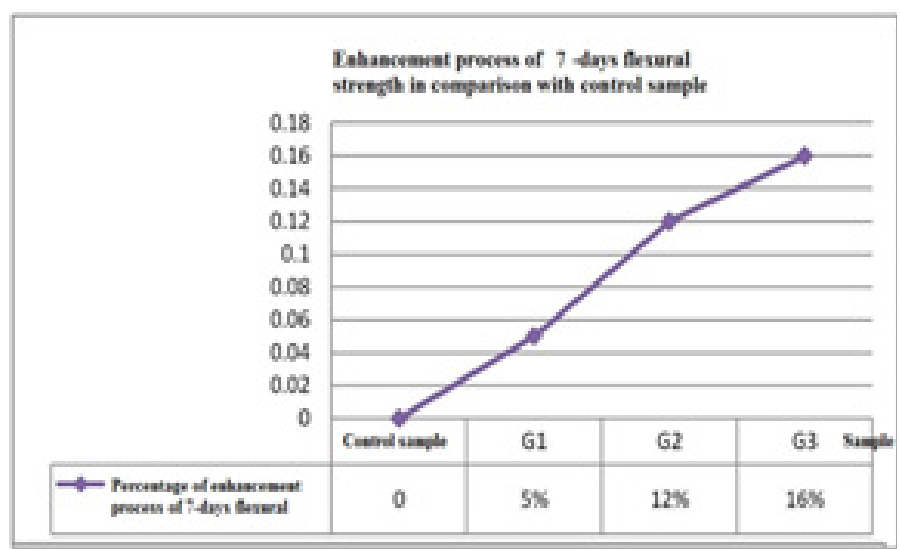

Figure 5 The enhancement process of 7 days flexural strength of LW concrete with glass fiber in comparison with control sample.

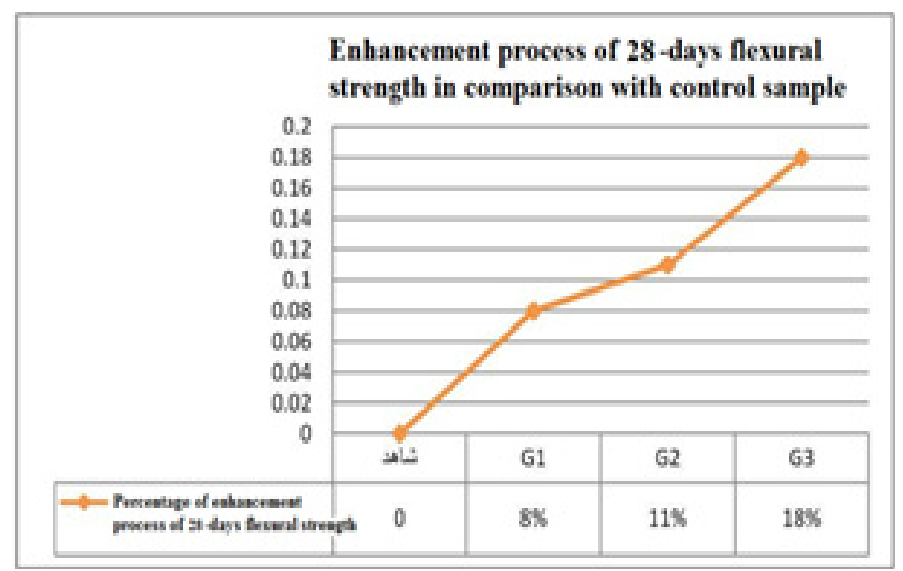

Figure 6 The enhancement process of 28 days flexural strength of LW concrete with glass fiber in comparison with control sample.

\section{The Comparison of flexural strength results}

In Figures $7 \& 8$, the LECA concrete with glass and polyolefin fibers are compared in terms of their flexural strength.

\section{Conclusions}

This study investigated the effect of Polyolefin Aramid and glass fiber based on flexural strength of LECA concrete. The amounts of used Polyolefin Aramid are 5, 5.2 and 5.7 in each cubic meter and 3, 5.4 and 6 for glass.

According to the indicated researches and tests, following results are obtained:

a) Polyolefin Aramid and glass fiber cause to increase the flexural strength in LECA concrete.

b) Increase strength of LECA concrete directly depends on the length and thickness of used fiber.

c) Using Polyolefin affect on increasing the flexural strength of LECA concrete which enhance around $45 \%$. In addition, the flexural strength will be enhanced by adding the number of fiber.

d) Glass fiber results in increasing the flexural strength of LECA concrete which raise around $18 \%$. Furthermore, the flexural strength will be increased by adding the number of fiber.

e) The flexural strength of samples increase with polyolefin fiber rather than glass fiber because of long length of polyolefin fiber and its material and thickness.

f) Due to 3-D reinforcing the concrete with fiber and distribute the fiber randomly, as long as the number of tests increase, the results will be more accurate.

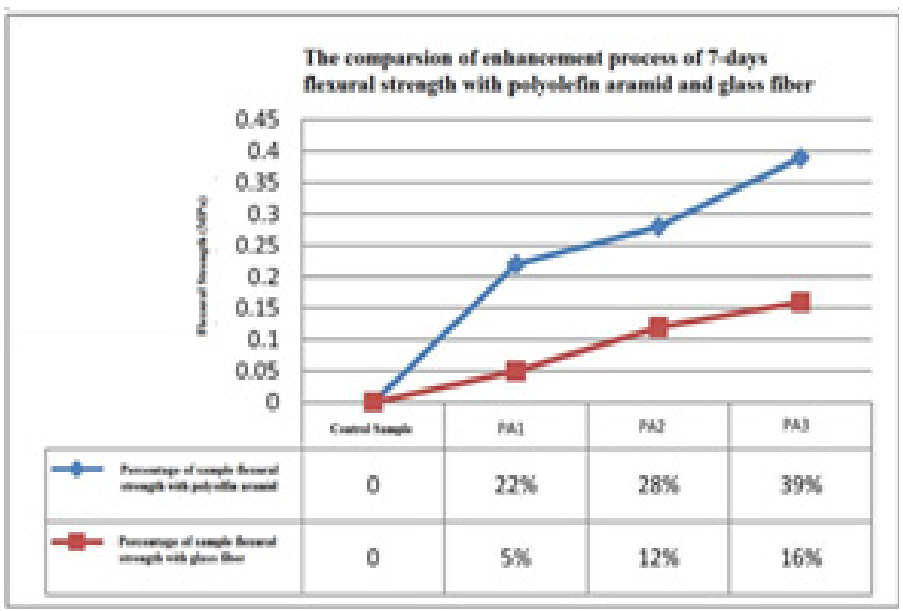

Figure 7 The enhancement process of 7 days flexural strength with polyolefin aramid and glass fiber. 


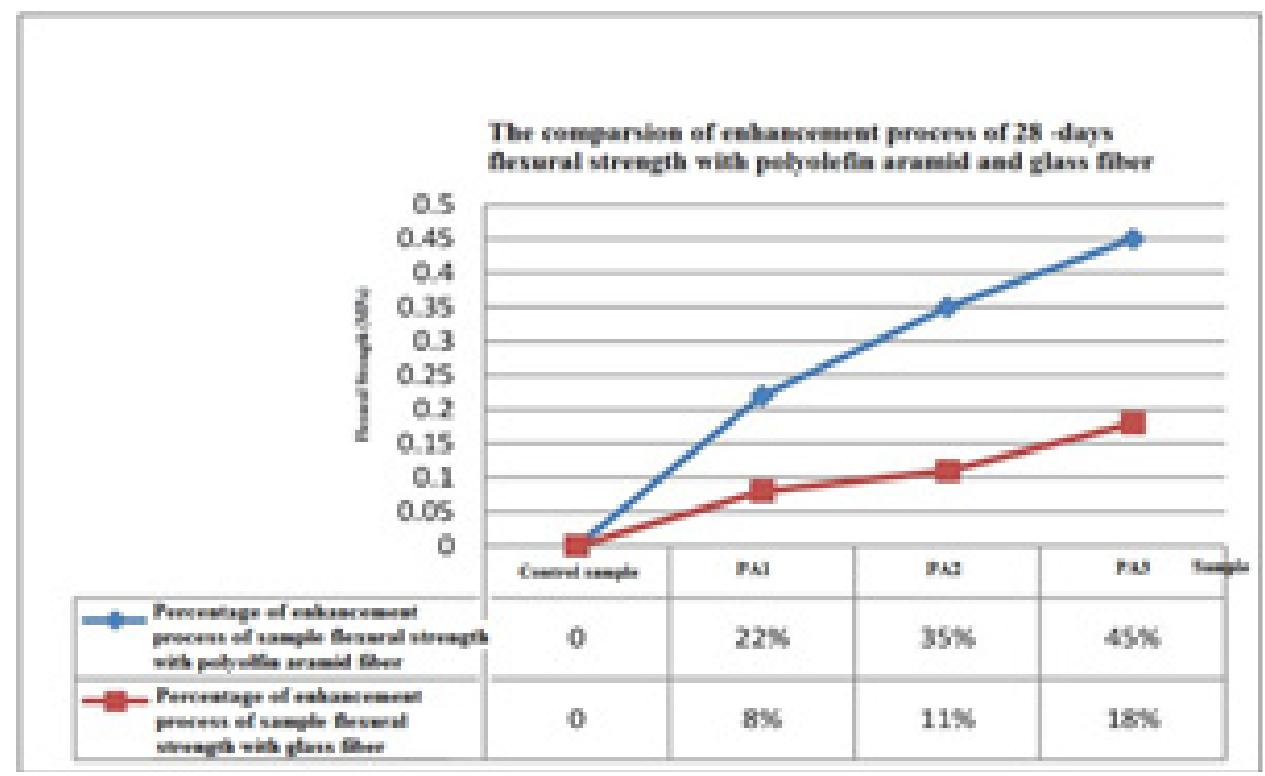

Figure 8 The enhancement process of 28 days flexural strength with polyolefin aramid and glass fiber.

\section{Acknowledgments}

None.

\section{Conflicts of interest}

The authors declare there is no conflict of interest.

\section{Funding}

None.

\section{References}

1. ACI 213R-87. Guide for Structural Lightweight Aggregate Concrete, American Concrete Institute, USA; 1999.

2. Tittarelli F, Carsana M, Ruello ML. Effect of hydrophobic admixture and recycled aggregate on physical-mechanical properties and durability aspects of no-fines concrete. Construction and Building Materials. 2014;66:30-37.

3. Song G, Wang L, Deng L, et al. Mechanical characterization and inclusion based boundary element modeling of lightweight concrete containing foam particles. Mechanics of Materials. 2015;91(1):208-225.

4. ASTM C330. Specification for Lightweight Aggregates for Structural Concrete. American Society of Testing Material, USA; 2004.

5. Alberti MG, Enfedaque A, Gálvez JC. Comparison between polyolefin fibre reinforced vibrated conventional concrete and self-compacting concrete. Construction and Building Materials. 2015;85:182-194.

6. ACI 5443 R-84. Report, ACI Proc. 1984;81:140-48.

7. Shah SP. Fiber Reinforced Concrete, in Handbook of Structural Concrete, New York, USA: McGraw-Hill Book Company; 1984.

8. Lipatov YV, Gutnikov SI, Manylov MS, et al. High alkali-resistant basalt fiber for reinforcing concrete. Materials and Design. 2015;73:60-66.
9. BS 1881. Testing Concrete, British Standard, USA; 1983.

10. ASTM C293. Standard Test Method for Flexural Strength of Concrete, USA: American Society of Testing Material; 2012.

11. Kumar PM, Paulo JM. Concrete (Microstructure, Properties, and Materials), New York,USA: McGraw-Hill; 2014.

12. ASTM, C150. Standard Specification for Portland Cement, USA: American Society of Testing Material; 2012.

13. Sanjuán MA, Argiz C, Gálvez JC, et al. Effect of silica fume fineness on the improvement of Portland cement strength performance. Construction and Building Materials. 2015;96:55-64.

14. ASTM C1202. Standard Test Method for Electrical Indication of Concrete's Ability to Resist Chloride Ion Penetration, USA: American Society of Testing Material; 2012.

15. ASTM C33m. Standard Specification for Concrete Aggregates, USA: American Society of Testing Material; 2013.

16. Alberti MG, Enfedaque A, Gálvez JC, et al. Polyolefin fiber-reinforced concrete enhanced with steel-hooked fibers in low proportions. Materials and Design. 2015;60:57-65.

17. Yoo DY, Zi G, Kang ST, et al. Biaxial flexural behavior of ultra-highperformance fiber-reinforced concrete with different fiber lengths and placement methods. Cement and Concrete Composites. 2015;63:51-66.

18. Wang L, Zhang J, Yang X, et al. Flexural properties of epoxy syntactic Foams reinforced by fiberglass mesh and/or short glass fiber. Materials and Design. 2014;55:929-936.

19. Majumdar AJ. Glass Fiber Reinforced Cement and Gypsum Products, Proc R Soc London [A. 1970;319:69-78.

20. Hamad AJ. Size and shape effect of specimen on the compressive strength of HPLWFC reinforced With glass fibres. Journal of King Saud University - Engineering Sciences in press. 2015;29(4):373-380. 
21. ACI. Standard Practice for Selecting Proportions for Normal, HeavyWeight and Mass Concrete, Manual of concrete Practice, USA; 1991

22. Neville AM. Properties of Concrete, Pitman publishing inc, Marshfield Mass, USA, 1981.

23. Ardakani A, Yazdani M. The Relation between particle density and static elastic module of lightweight expanded clay aggregates. Applied Clay Science. 2014;93-94:28-34.
24. Cement Concrete \& Aggregates Australia. CONCRETE BASICS A Guide to Concrete Practice, Australia, 2004.

25. ASTM, C192. Making and Curing Concrete Test Specimens in the Laboratory, Annual Book of ASTM, USA; 2002.

26. Khaled M, Özgür E, Tahir Ç. Relationship between flexural toughness energy and impact energy of high strength fiber reinforced concrete (HSFRC). Materiales de Construcción. 2001;51(262):5-13. 